\title{
A Study On Quality Of Work Life: Key Elements \& It's Implications
}

\author{
Shefali Srivastava, Rooma Kanpur \\ Assistant Professor, (Axis Colleges)
}

\begin{abstract}
In modern era, it has been observed that stress management has become one of the most substantial conceptsin the professional environment. It is also seen that working efficiency has degraded to some extent as professionals are unable to maintain a balance between their personal and professional lives. This difference has made organizations to formulate such policies that lead to better job performance which results in job satisfaction moreover employee satisfaction. This degree of satisfaction has been referred to as QUALITY OF WORK LIFE. Quality of work life is a process in an organization which enables its members at all levels to participate actively and effectively in shaping organizational environment, methods and outcomes. This study focuses on the subjective matter of QWL i.e. its key elements like job security, job performance, employee satisfaction etc.
\end{abstract}

Keywords: Quality of work life, job performance, employee satisfaction, job security.

\section{Introduction}

Quality of Work Life is the existence of a certain set of organizational conditions or practices. This definition frequently argues that a high quality of work life exists when democratic management practices are used, employee's jobs are enriched, employees are treated with dignity and safe working conditions exist. In recent years the phrase "Quality of life" has been used with increasing frequency to describe certain environmental and humanistic values neglected by industrial productivity and economic growth. Within business organizations attention has been focused on the Quality of human experience in the work place. At the same time many firms have questioned their viability in increasingly competitive world markets. These dual concerns have created a growing interest in the possibilities of redesigning the nature of work. Many current organizational experiments seek to improve both productivity for the organization and the quality of working life for its members.

Quality can be assessed by factors like performance, reliability, aesthetics, and complying with customer requirements. Quality refers to "freedom from wastage, freedom from trouble and freedom from failure".

Quality of Work Life refers to the level of satisfaction, motivation, involvement and commitment individuals experience with respect to their lives at work.

Quality of Work Life is the degree to which individuals are able to satisfy their important personal needs while employed by the firm. Companies interested in enhancing employees Quality of Work Life generally try to instill in employees the feelings of security, equity, pride, internal democracy, ownership, autonomy, responsibility and flexibility. They try to treat employees in a fair and supportive manner, open communication channels at all levels, offer employees opportunities to participate in decisions affecting them and empower them to carry on with their assignments. It has also been associated with organizational changes aimed at increasing the levels of job widening (greater horizontal task flexibility) and job enrichment (greater vertical task flexibility including the taking on of new responsibilities including those formerly undertaken by supervisory or managerial personnel). Crucially, the idea is that of attaining higher levels of involvement and thereby motivation by improving the attractiveness of the work itself rather than through improving the terms and conditions of work (Hertzberg). Quality of life phenomena explored in early studies included job satisfaction (measured by employee turnover, absenteeism or attitude surveys), organizational climate and the learning of new tasks.

\section{Who Needs Quality of Work Life?}

We know that we just can't stop "working at it", discovering, creating and sharing new stuff. We're all so busy psychologically; work has always been one of the most significant of human experiences. But when for many people sex and relationships are troublesome since they are often hazardous to our health work plays an even greater role in keeping us "out of trouble." Regardless of how much we earn, most of us have some kind of agenda or work plan.

And with so many people opening a home and a cyber-office, with mounting levels of technology-related stress, owner turned content. Many of us end up involved in more than one job, which we feel compelled to get 
done, spending the greatest portion of our lives in what we consider our workplace. SoQWL is not some notion of frivolous luxury. QWL is just as real and useful as virtual reality itself. The brainchild of Quality of Work Life Services, Manhattan-based, woman-created enterprise, QWL SPACE has been occupied by equally experienced, open-minded, goal- king of free days before national holidays have been separately stipulated. The differences regarding the working time have been established for the persons less than 18 years of age, pregnant women, breast-feeding mothers and the person raising the disabled child. The appropriate salary is agreed upon by the employee and the employer. The Government of the Republic establishes each year the rate of minimum salary; the employer should not pay less than that to the employee.Work represents such a role in life which has been designated to it by the person himself. On the one hand work is an earning of one's living for the family, on the other hand it could be a self-realization providing enjoyment and satisfaction. We know that we just can't stop "working at it", discovering, creating and sharing new stuff. We're all so busy psychologically; work has always been one of the most significant of human experiences. But when for many people sex and relationships are troublesome since they are often hazardous to our health work plays an even greater role in keeping us "out of trouble." Regardless of how much we earn, most of us have some kind of agenda or work plan.

\section{Key elements:}

Promote human dignity and growth

Work together collaboratively

Participative determine work changes

Assume comparability of people and organizational goal

\section{HUMANISED WORK THROUGH QUALITY OF WORK LIFE}

One option is to re-design jobs to have the attributes desired by people, and re-design organisations to have the environment desired by the people. This approach seeks to improve QWL. There is a need to give workers more of a challenge, more of a whole task, more opportunity to use their ideas. Close attention to QWL provides a more humanised work environment. It attempts to serve the higher-order needs of workers as well as their more basic needs. It seeks to employ the higher skills of workers and to provide an environment that encourages them to improve their skills. The idea is that human resources should be developed and not simply used. Further, the work should not have excessively negative conditions. It should not put workers under undue stress. It should not damage or degrade their humanness. It should not be threatening or unduly dangerous. Finally, it should contribute to, or at least leave unimpaired, workers' abilities to perform in other life roles, such as citizen, spouse and parent. That is, work should contribute to general social advancement.

\section{Job Enlargement vs. Job Enrichment}

The modern interest in quality of work life was stimulated through efforts to change the scope of people's jobs in attempting to motivate them. Job scope has two dimensions - breadth and depth. Job breadth is the number of different tasks an individual is directly responsible for. It ranges from very narrow (one task performed repetitively) to wide (several tasks). Employees with narrow job breadth were sometimes given a wider variety of duties in order to reduce their monotony; this process is called job enlargement. In order to perform these additional duties, employees spend less time on each duty. Another approach to changing job breadth is job rotation, which involves periodic assignment of an employee to completely different sets of job activities. Job rotation is an effective way to develop multiple skills in employees, which benefits the organisation while creating greater job interest and career options for the employee.

\section{APPLICATIONS}

Viewed in terms of Herzberg's motivational factors, job enrichment occurs when the work itself is more challenging, when achievement is encouraged, when there is opportunity for growth and when responsibility, feedback and recognition are provided. However, employees are the final judges of what enriches their jobs. All that management can do is gather information about what tend to enrich jobs, try those changes in the job system and then determine whether employees feel that enrichment has occurred.In trying to build motivational factors, management also gives attention to maintenance factors. It attempts to keep maintenance factors constant or higher as the motivational factors are increased. If maintenance factors are allowed to decline during an enrichment program, then employees may be less responsive to the enrichment program because they are distracted by inadequate maintenance. The need for a systems approach in job enrichment is satisfied by the practice of gain sharing. Since job enrichment must occur from each employee's personal viewpoint, not all employees will choose enriched jobs if they have an option. A contingency relationship exists in terms of different job needs, and some employees prefer the simplicity and security of more routine jobs. 


\section{The Human Resource Department's Role}

The role of human resource department in QWL efforts varies widely. In some organizations, top management appoints an executive to ensure that QWL and productivity efforts occur throughout the organization. In most cases, these executives have a small staff and must rely on the human resource department for help with employee training, communications, attitude survey feedback, and similar assistance. In other organizations, the department is responsible for initiating and directing the firm's QWL and productivity efforts. Perhaps the most crucial role of the department is winning the support of key managers. Management support particularly top management support appears to be an almost universal prerequisite for successful QWL programs. By substantiating employee satisfaction and bottom-line benefits, which range from lower absenteeism and turnover to higher productivity and fewer accidents, the department can help convince doubting managers. Sometimes documentation of QWL can result from studies of performance before and after a QWL effort. Without documentation of these results, top management might not have continued its strong support.

The department also has both a direct and indirect influence on employee motivation and satisfaction.The policies and practices of the department also influence motivation and satisfaction indirectly. Rigorous enforced safety and health programs, for example, can give employees and supervisors a greater sense of safety from accidents and industrial health hazards. Likewise, compensation policies may motivate and satisfy employees through incentive plans, or they may harm motivation and satisfaction through insufficient raises or outright salary freezes. The motivation and satisfaction of employees act as feedback on the organisation's QWL and on the department's day-to-day activities.

\section{Motivation}

Motivation is a complex subject. It involves the unique feelings, thoughts and past experiences of each of us as we share a variety of relationships within and outside organisations. To expect a single motivational approach work in every situation is probably unrealistic. In fact, even theorists and researches take different points of view about motivation. Nevertheless, motivation can be defined as a person's drive to take an action because that person wants to do so. People act because they feel that they have to. However, if they are motivated they make the positive choice to act for a purpose - because, for example, it may satisfy some of their needs.

\section{Job Satisfaction}

Job satisfaction is the favorableness or unfavourableness with which employees view their work. As with motivation, it is affected by the environment. Job satisfaction is impacted by job design. Jobs that are rich in positive behavioural elements - such as autonomy, variety, task identity, task significance and feedback contribute to employee's satisfaction. Likewise, orientation is important because the employee's acceptance by the work group contributes to satisfaction. If better performance leads to higher rewards and if these rewards are seen as fair and equitable, then results in improved satisfaction. On the other hand, inadequate rewards can lead to dissatisfaction. In either case, satisfaction becomes feedback that affects one's self-image and motivation to perform. The total performance-satisfaction relationship is a continuous system, making it difficult to assess the impact of satisfaction on motivation or on performance, and vice-versa.

\section{Objectives of Quality of Work Life:}

- To increase in individual productivity, accountability and commitment.

- For better teamwork and communication.

- For improving the morale of employees.

- To reduce organizational stress.

- To improve relationships both on and off the job.

- To improve the safety working conditions.

- To provide adequate Human Resource Development Programs.

- To improve employee satisfaction.

- To strengthen workplace learning.

- To better manage on-going change and transition.

- To participate in management at all levels in shaping the organization.

\section{Importance of Quality of Work Life:}

Improved Quality of Work Life was not considered as important factor in India until recently as there were important impending factors like resource deficiency, environmental threats and some services of financial problems.

Quality of Work Life program has become important in work place for the following reasons:

1. Increase demands at work

2. Loss of long term employee guarantees 
3. The need for enhanced work place skills

4. Greater competition for talent

5. Increased women in work force

Good quality of Work Life leads to an atmosphere of good impersonal relations and highly motivated employees who strive for their development. Though monetary benefits still occupy the first place in the cost of elements like physical working conditions, job restructuring and job re-designing, career development, promotional opportunities etc. are gaining importance rapidly. As such, workers expect the management to improve all these facilities which thereby improve Quality of Work life. If provided with good Quality of Work Life, employees concentrate more on both individual as well as group development which in turn leads to overall development.

According to Walton (1975) proposed eight conceptual categories. They are as follows:

$\begin{array}{cl}\circ & \text { Adequate and fair compensation } \\ \circ & \text { Safe and healthy working conditions } \\ \circ & \text { Immediate opportunity to use and develop human capacities } \\ \circ & \text { Opportunity for continued growth and security } \\ \circ & \text { Social integration in the work organization } \\ \circ & \text { Constitutionalization in the work organization } \\ \circ & \text { Work and the total life span } \\ \circ & \text { The social relevance of work life }\end{array}$

Successful organization is turning through the introduction of Quality of Work Life strategy to the people who work in them to maintain competitive advantage. The benefits to both management and workers include:

1. Improved organization performance through the development of people.

2. Increased co-operation and team work within and across all the levels of the organization including movement towards management or trade union partnership.

3. Increased environment in doing a good job .

4. Improved quality performance.

5. Increased commitment to the values and goals of the organization.

6. The anchoring of the development of a quality organization

\begin{tabular}{|c|c|}
\hline $\begin{array}{l}\text { WORK-LIFE BALANCE } \\
\text { BENEFITS TO THE ORGANIZATION }\end{array}$ & $\begin{array}{l}\text { WORK-LIFE BALANCE } \\
\text { BENEFITS TO THE INDIVIDUAL }\end{array}$ \\
\hline $\begin{array}{ll}\text { - } & \text { Measured increases in individual } \\
\text { productivity accountability and } \\
\text { commitment } \\
\text { - } \\
\text { - } \text { Better teamwork and communication } \\
\text { - } \\
\text { Improved morale } \\
\text { Less negative organizational stress }\end{array}$ & $\begin{array}{l}\text { - More value and balance in your daily life } \\
\text { - Better understanding of what your best } \\
\text { individual work life balance is } \\
\text { - Increased productivity } \\
\text { - Improved relationships both on and off the } \\
\text { job } \\
\text { - Reduced stress }\end{array}$ \\
\hline
\end{tabular}

About QWL Strategy:

- Improve communication with employees

- Strengthen family friendly programs

- Provide all employees with Internet access

- Increase investment in workplace learning

- Improve the effectiveness of supervisors and team leaders

- Evaluate the effectiveness of diversity management practices and

- Improve ability to manage change and transition

The programs, policies and services through Quality of Work life Programs:

- Support faculty and staff efforts to manage the competing demands of work and personal life

- Support health promotions and wellness

- Express appreciation for faculty and staff contribution to the university, highlight outstanding individual contributions and recognize long term commitment.

Quality of Work Life as a process:

The concept of Quality of Work Life views a work as a process of interaction and joint problem solving by work in people, managers, supervisors and workers.

This process is:

i. Co-operative rather than authoritarian

ii. Evolutionary and changing rather than static 
iii. Open rather than rigid

iv. Informal rather than rule based

v. Problem solving

Quality of Work life programme has become important in the work place for the following reasons:

- Increased women in work force

- Increased male involvement in dependant care activities

- Increased responsibilities for elders

- Increased demand at work

- Loss of long term employment guarantees

- The need for enhanced work place skills

- Greater competition for talent

The following are the some of the specific issues in Quality of Work life

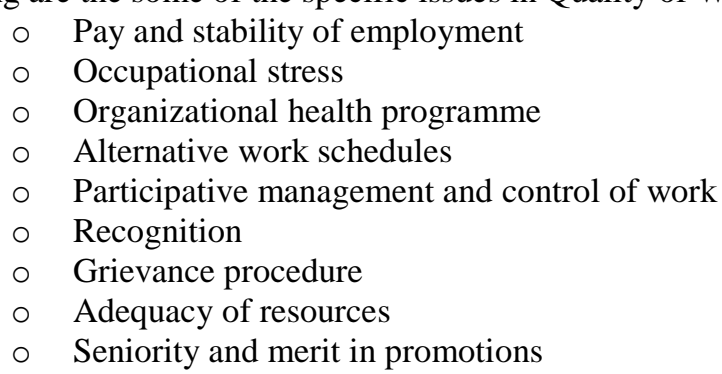

Problems of implementing Quality of Work Life programmes:

Bohlander has identified three common problems of implementing Quality of Work Life programme. The three areas are:

- Managerial attitudes

- Union influence

- Restrictiveness of industrial engineering

Strategies to improve Quality of Work Life: By implementing some changes, the management can create sense of involvement, commitment and togetherness among the employees which paves way for better Quality of Work Life.

a. Job enrichment and Job redesign

b. Autonomous work redesign

c. Opportunity for growth

d. Administrative or organizational justice

e. Job security

f. Suggestion system

g. Flexibility in work schedules

h. Employee participation

Quality of Work life improvements are defined as any activity which takes place at every level of an organization which seeks greater organizational effectiveness through the enhancement of human dignity and growth. A process through which the state holders in the organization, management, unions and employees - learn how to work together better to determine for themselves what actions, changes and improvements are desirable and workable in order to achieve the win and simultaneous goals of an improved quality of life at work for all members of the organization and greater effectiveness for both the company and the unions.

\section{Conclusion}

The above discussion has helped me to conclude that the identification of the measures of quality of life is indeed a difficult task, though there is a sort of common agreement on its concept of employee wellbeing. Evidently there are objective (physical and structural design) factors that provide work place setting and intervening policy factors that affect work processes of employees. As regards the outcome factors the immediate effects on psychology of employees (positive attitudes, commitment, and satisfaction) and ultimate effects on performance of organization are being considered by researchers. Finally it is very true to say that high degree of QWL leads to job satisfaction which ultimately results in effective and efficient performance. 


\section{BOOKS:}

\section{References}

[1]. Robbins, S.P. Organizational Behavior: Concepts, Controversies, and Applications, Prentice-Hall, Englewood Cliffs,

[2]. Klatt, Murdick and Schuster (1985), Human resource Management, Ohio, Charter E.Merrul Publishing Company.

[3]. Casio, W.F,(1998), Managing human resources: productivity, quality of work life, profits, Irwin: McGraw-Hill,

[4]. Schermernrhorn, J.R., John, R, Management for Productivity, John Wily and Sons: Inc

[5]. Hackman, J.R. and Oldham, G.R. (1980), Work Redesign, Addison-Wesley, Reading, MA.

Boston, MA.

\section{JOURNALS:}

[1]. Kalra, S. K., \& Ghosh, S. Quality of work life: A study of associated factors. The Indian Journal of Social Work, 1984, 45-54.

[2]. Elizur, D., \& Shye, S. Quality of work life and its relation to quality of life. Applied Psychology: An International Review, 39 (3), .1990, 275-291.

[3]. Hannif, Zeenobiyah \& et.al, Call Centers and the Quality of Work Life: Towards a Research Agenda, Journal of Industrial Relations, 50(2), 2008, 271-284

[4]. Hsu, M. Y., \& Kernohan, G. Dimensions of hospital nurses' quality of working life. Journal of Advanced Nursing, 54, 2006, 120131.

[5]. Korunka, C., Hoonakker, P., \& Carayon, P. Quality of working life and turnover intention in information technology work. Human Factors and Ergonomics in Manufacturing \& Service Industries, 18, 2008, 409-423.

[6]. Lewis, D., Brazil, K., Krueger, P., Lohfeld, L., \& Tjam, E. Extrinsic and intrinsic determinants of quality of work life. Leadership in Health Services, 14, 2001, 9-15.

[7]. Schouteten, R. Group work in a Dutch home care organization: Does it improve the quality of working life? The International Journal of Health Planning and Management, 19, 2004, 179-194.

[8]. Van Laar, D., Edwards, J. A., \& Easton, S. The Work-related quality of life scale for healthcare workers. Journal of Advanced Nursing, 60, 2007, 325-333.

[9]. Walton, R.E. Improving the QWL, Harvard Business Review, 19 (12), May-June, 1980, 11-24. [10] Winter, R., Taylor, T. and Sarros, J., Trouble at Mill, "Quality of Academic work life issues within a comprehensive Australian University", Studies in Higher Education, 25 (3), 2000, 279-294. 